This PDF is a selection from an out-of-print volume from the National Bureau of Economic Research

Volume Title: An Appraisal of the 1950 Census Income Data

Volume Author/Editor: Conference on Research in Income and Wealth

Volume Publisher: Princeton University Press

Volume ISBN: 0-691-04102-4

Volume URL: http://www.nber.org/books/unkn58-2

Publication Date: 1958

Chapter Title: The Effect of Multi-Industry Employment on the Industrial Distribution of Wages

Chapter Author: Lazare Teper

Chapter URL: http://www.nber.org/chapters/c1060

Chapter pages in book: (p. 431 - 446) 


\title{
The Effect of Multi-Industry Employment on the Industrial Distribution of Wages
}

\author{
LAZARE TEPER, INTERNATIONAL LADIES' GARMENT \\ WORKERS' UNION
}

Herman P. Miller's paper brings together valuable material on the distributions of annual wage and salary earnings in 1939 and 1949 and on their changing patterns in order to identify "some of the variable as well as the stable elements of the distribution of income," to determine "the underlying forces responsible for the change," and to establish "what general lessons can be learned from the changes for specific industry groups."

\section{Extent of Multi-Industry Employment}

In the main, Miller relies on data gathered by the Bureau of the Census in the course of the decennial enumerations. Such data are limited somewhat by how specific and accurate the average respondent can be. Industrial and occupational characteristics of earnings have to be somewhat broader, and unquestionably somewhat vaguer, than those obtainable in an establishment enumeration. ${ }^{1}$ As a result, census occupational designations frequently encompass a variety of jobs varying in content and paid on the basis of widely different standards. For example, the occupation of a sewing machine operator includes jobs differing in skill and occupational requirements and paid at substantially different rates. A swing in the relative importance of specific groups within an occupational class may affect the average level for the group even in the absence of wage movement. The effect is apt to be more pronounced for broad occupational groups, such as skilled, semiskilled, and unskilled. It is impossible to determine, in view of the heterogeneity of jobs within such categories, to what extent the particular changes are a result of the changing mix of jobs.

Census data on annual earnings by industry and occupation are collected and classified on the basis of the last job held (whether for

\footnotetext{
${ }^{1}$ Recognizing this problem, Australia, in connection with its 1954 population census, conducted a sample survey among employers regarding the industrial and occupational classification of their employees (United Nations Statistical Commission, 9th session, Minutes of the 131st meeting, document E/CN.3/SR.131).
} 
hire, unpaid family work, or in self-employment) by persons who are in the labor force during the census week. ${ }^{2}$ For those employed it is the job held during that week, or in the case of persons holding more than one job, the one in which most hours were worked during the week. For those unemployed, it is the last job held. ${ }^{3}$ In consequence, an individual is not necessarily classified under the industry and occupation in which the greatest portion of his wage and salary income was earned in the preceding year.

Classification of workers by industry and occupation of last employment provides a valuable yardstick for the evaluation of labor force characteristics at a given time. Yet it unavoidably introduces an element of uncertainty when such data are related to annual earnings of individuals in order to trace changes in interindustry or interoccupational relationships of incomes. It is impossible to differentiate, for example, between the effect of the changing earnings opportunities in a given industrial classification from that brought about by work outside the particular industrial subdivision.

Some insight into this problem is provided by sample data gathered by the Bureau of Old-Age and Survivors Insurance on covered workers. But social security taxes are not always paid on the full amount of annual earnings because of the statutory limits on the taxable amount. This affects the amount reported as taxable wages. Averages derived from such data and changes portrayed by them over a period of time are influenced by the changes in the relative importance of annual incomes which exceed taxable limits. Furthermore, earnings in noncovered employment are not reported to the Bureau. As a result, the level of average annual wages and the extent of multi-industry employment tend to be understated.

Table 1 shows that multi-industry employment is both substantial and variable from year to year. Thus in the 1944-1952 period multi-industry employment (in more than one two-digit industry) ${ }^{4}$ of male wage and salary earners varied from 23.7 to 34.7 per cent and of females from 16.1 to 31.7 per cent. The prevalence of multi-industry employment would loom even larger, and more variable, if data were available on a more refined industry

'The census week is defined as the week preceding the enumerator's visit.

${ }^{3}$ Occupational and industrial information is not collected for persons outside the labor force during the census week even though they may have worked in the preceding year.

* The Standard Industrial Classification, prepared by the Bureau of the Budget and used by the Bureau of Old-Age and Survivors Insurance, provides for grouping industrial activities into nine major divisions. These divisions are divided into major groups coded on a two-digit basis; these are then subdivided into groups of closely related industries coded on a three-digit basis, and further subdivided on the basis of a four-digit code. 
TABLE 1

Percentage of All Wage and Salary Earners Who Worked in Covered Employment in More than One Two-Digit Industry in the Year, by Sex, 1944-1952

\begin{tabular}{ccc}
\hline \hline YEAR & Males & Females \\
\hline 1944 & 34.7 & 31.7 \\
1945 & 32.9 & 29.1 \\
1946 & 33.4 & 26.8 \\
1947 & 28.7 & 21.1 \\
1948 & 27.6 & 19.4 \\
1949 & 23.7 & 16.1 \\
1950 & 26.3 & 17.5 \\
1951 & 29.8 & 20.3 \\
1952 & 29.6 & 20.2 \\
\hline
\end{tabular}

For an explanation of "two-digit industry" see note 4 in the text.

Source: Handbook of Old Age and Survivors Insurance Statistics, Bureau of Old Age and Survivors Insurance, Volumes for 1944 through 1952.

classification, and also, as previously noted, if non-covered jobs were recorded.

The extent of multi-industry employment, furthermore, differs widely from industry to industry. The broad patterns of this variability can be seen from oASI data for the eight major industrial groups presented in Table 2, which shows the extent of multi-industry employment among male workers classified by industry of last employment for the years 1944 through $1949 .{ }^{5}$ Such data are not

TABLE 2

Percentage of Male Workers by Industry in Which Last Employed Who Were Also Employed in Other Industries, 1944-1949

\begin{tabular}{lcccccc}
\hline \hline \multicolumn{1}{c}{ INDUSTRY } & 1944 & 1945 & 1946 & 1947 & 1948 & 1949 \\
\hline Agriculture, forestry, and & & & & & & \\
$\quad$ fishing & 41.7 & 44.5 & 41.9 & 43.7 & 38.7 & 34.6 \\
Mining & 31.9 & 26.6 & 27.5 & 22.3 & 19.2 & 14.4 \\
Contract construction & 58.6 & 55.2 & 48.9 & 50.2 & 44.3 & 42.4 \\
Manufacturing & 28.4 & 28.9 & 31.0 & 25.1 & 21.3 & 17.0 \\
Public utilities & 43.1 & 34.4 & 28.4 & 29.6 & 28.1 & 24.0 \\
Wholesale and retail trade & 38.0 & 31.9 & 32.5 & 27.8 & 30.0 & 25.6 \\
Finance, insurance, and & & & & & & \\
$\quad$ real estate & 31.5 & 23.4 & 29.0 & 21.3 & 24.4 & 21.9 \\
Service industries & 44.6 & 31.3 & 33.9 & 25.3 & 33.3 & 28.6 \\
\hline
\end{tabular}

For a definition of "industry in which last employed" see note 5 in the text.

Source: Handbook of Old-Age and Survivors Insurance Statistics, Bureau of Old-Age and Survivors Insurance, volumes for 1944 through 1949.

"The concept of "last employment" in the oasi and census usage is not the same. The OASI Bureau classifies a worker by the industry of last employment on the basis of the industry of the first employer report tabulated for the last calen- 
available for later years, but Table 3 shows the relative importance of multi-industry workers for each major industrial group in which they were actually employed. ${ }^{6}$ It is clear that at different times earn-

TABLE 3

Percentage of Male Workers by Industry in Which Actually Employed

Who Were Also Employed in Other Industries, 1949-1952

\begin{tabular}{lcccc}
\hline \hline \multicolumn{1}{c}{ INDUSTRY } & 1949 & 1950 & 1951 & 1952 \\
\hline Agriculture, forestry, and fishing & 59.2 & 60.5 & 43.0 & 44.7 \\
Mining & 27.7 & 30.6 & 37.7 & 39.5 \\
Contract construction & 49.0 & 51.5 & 64.0 & 63.9 \\
Manufacturing & 23.0 & 25.9 & 35.8 & 36.1 \\
Public utilities & 38.5 & 41.7 & 48.9 & 48.2 \\
Wholesale and retail trade & 34.2 & 37.4 & 47.4 & 47.4 \\
Finance, insurance, and real estate & 36.9 & 39.2 & 44.1 & 43.0 \\
Service industries & 45.8 & 49.4 & 54.7 & 54.2 \\
\hline
\end{tabular}

For a definition of "industry in which actually employed" see note 6 in the text.

Source: Handbook of Old-Age and Survivors Insurance Statistics, Bureau of Old-Age and Survivors Insurance, volumes for 1949 through 1952.

ings outside of a particular industry have a different effect on the total recorded earnings.

\section{Effect of Patterns of Employment on Annual Earnings}

A more comprehensive portrayal of the effects of multi-industry employment is seen in Table 4. It shows, for the year 1949, the extent of multi-industry employment among male workers classified both by industry of last employment and by industry of actual employment, and gives the average annual earnings related to the patterns of employment. The range of variation in the proportion of multiindustry work in the different two-digit industries was from 7.8 to 45.8 per cent when employees were classified by industry of last employment, and from 15.1 to 67.6 per cent when classified by industry of actual employment. In ten two-digit industries out of sixty-eight, multi-industry workers (classified by industry of last employment) earned more than those whose employment was con-

dar quarter in which the worker had covered employment during the year (Handbook of Old-Age and Survivors Insurance Statistics, Bureau of Old-Age and Survivors Insurance, 1947 , p. 23). It is both industry and employment in which wages were earned in the particular year, although not necessarily the industry which gave rise to all of the earnings. The Census Bureau concept of classification relates to a different period from the one in which the particular worker had earnings, and is not limited to work for wages or salaries.

- OASI data by industry of actual employment relate to all persons who worked in a given industry in the course of the year. Persons who worked in more than one industry are thus counted in each. 


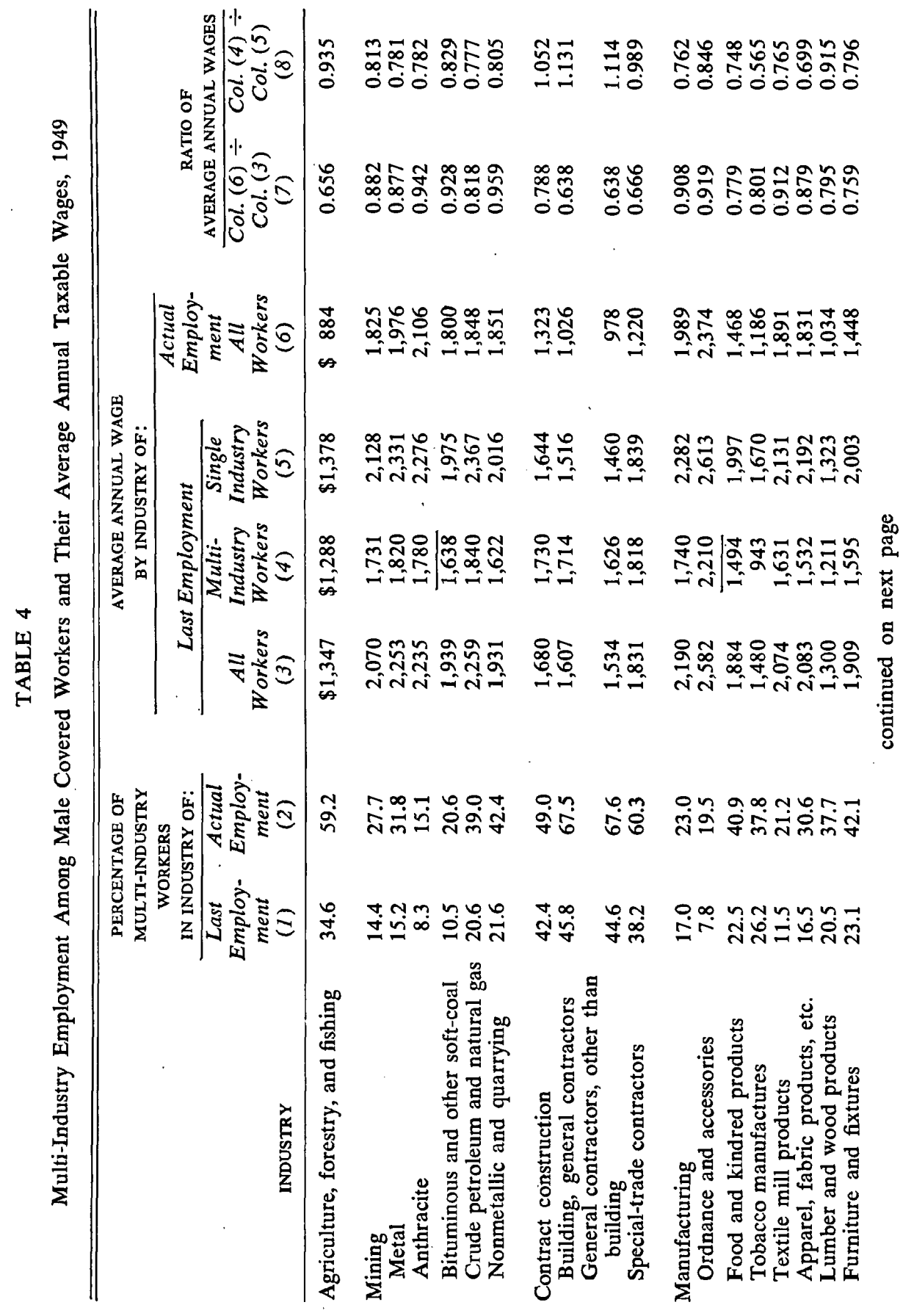




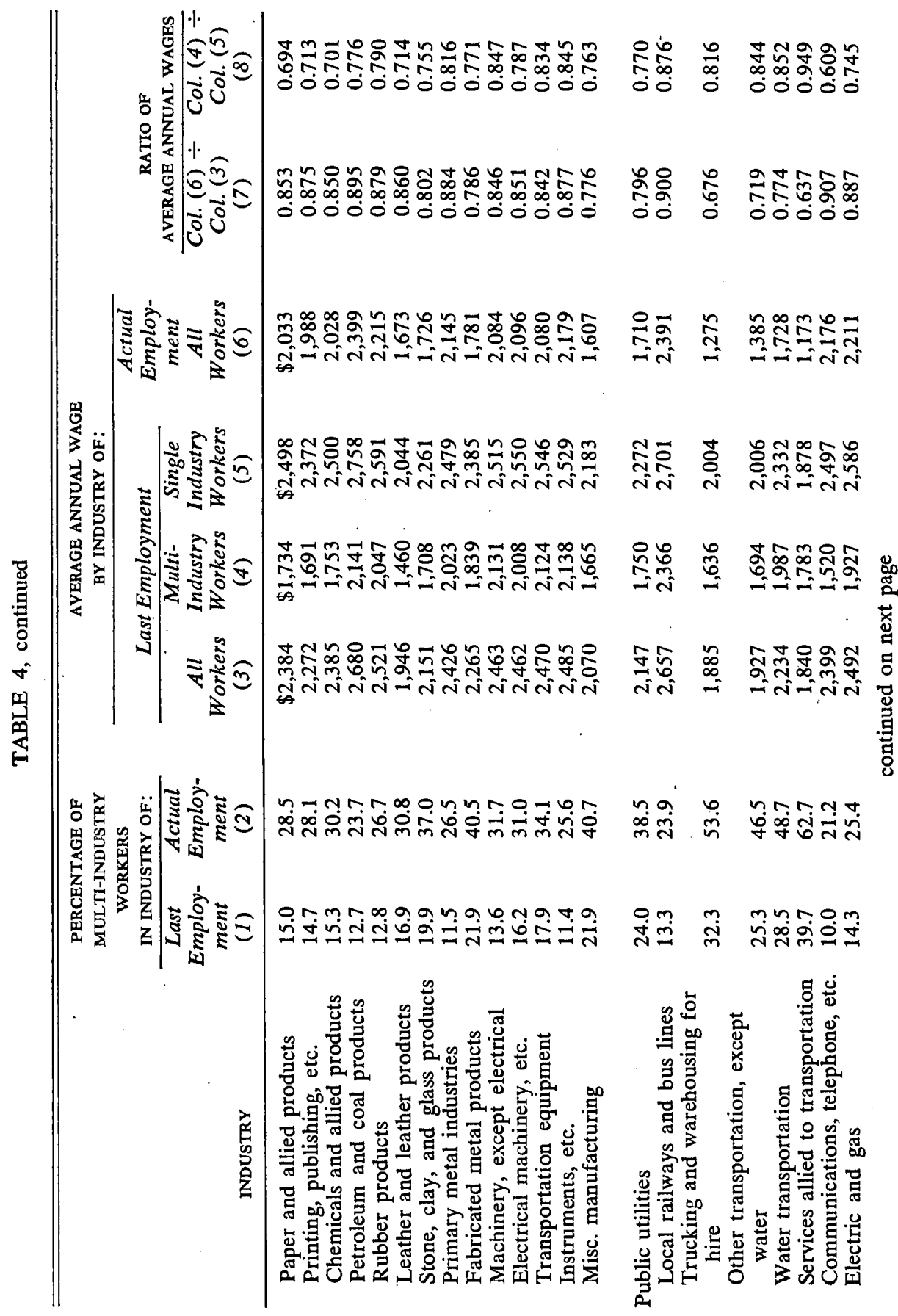




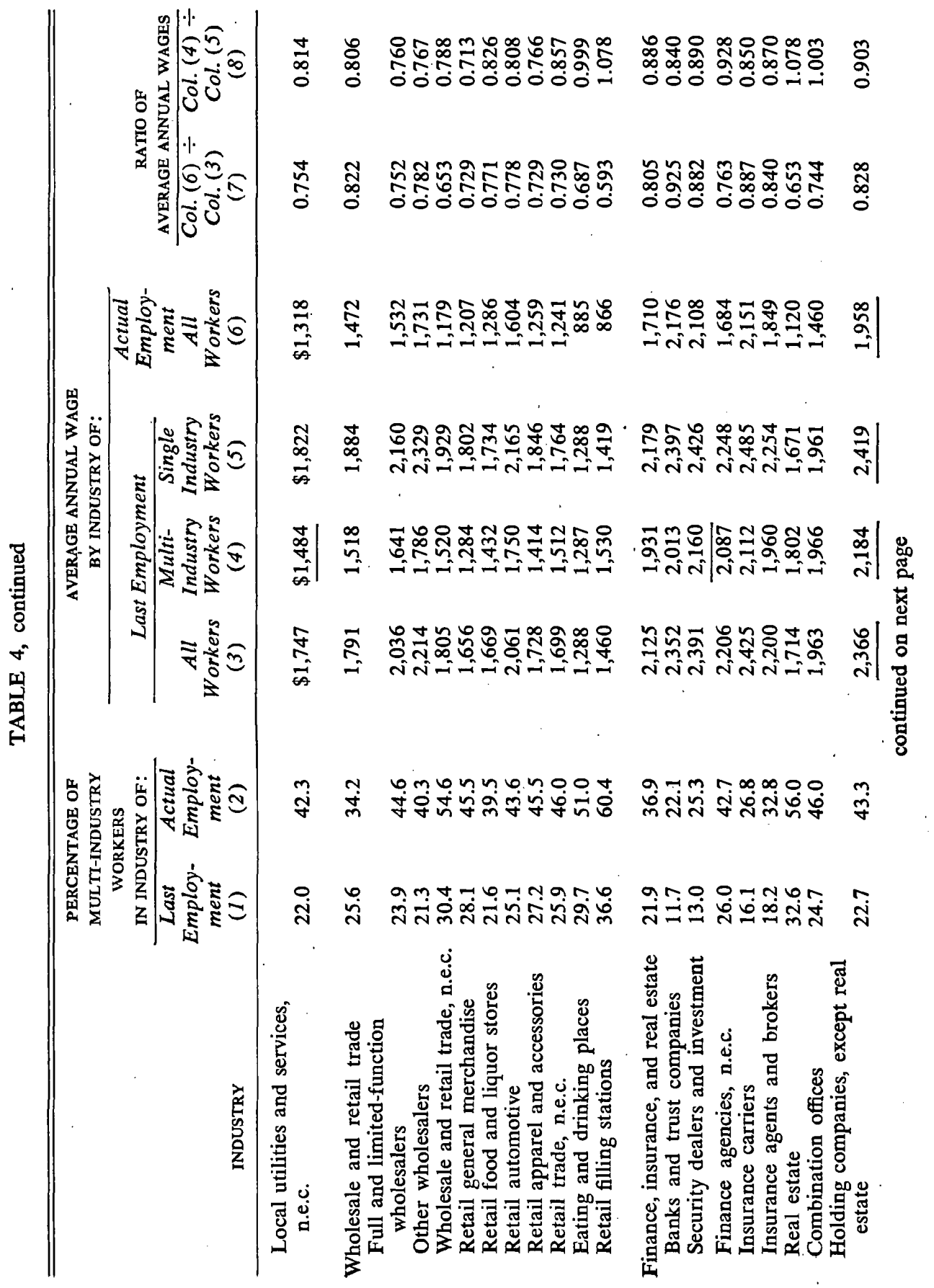




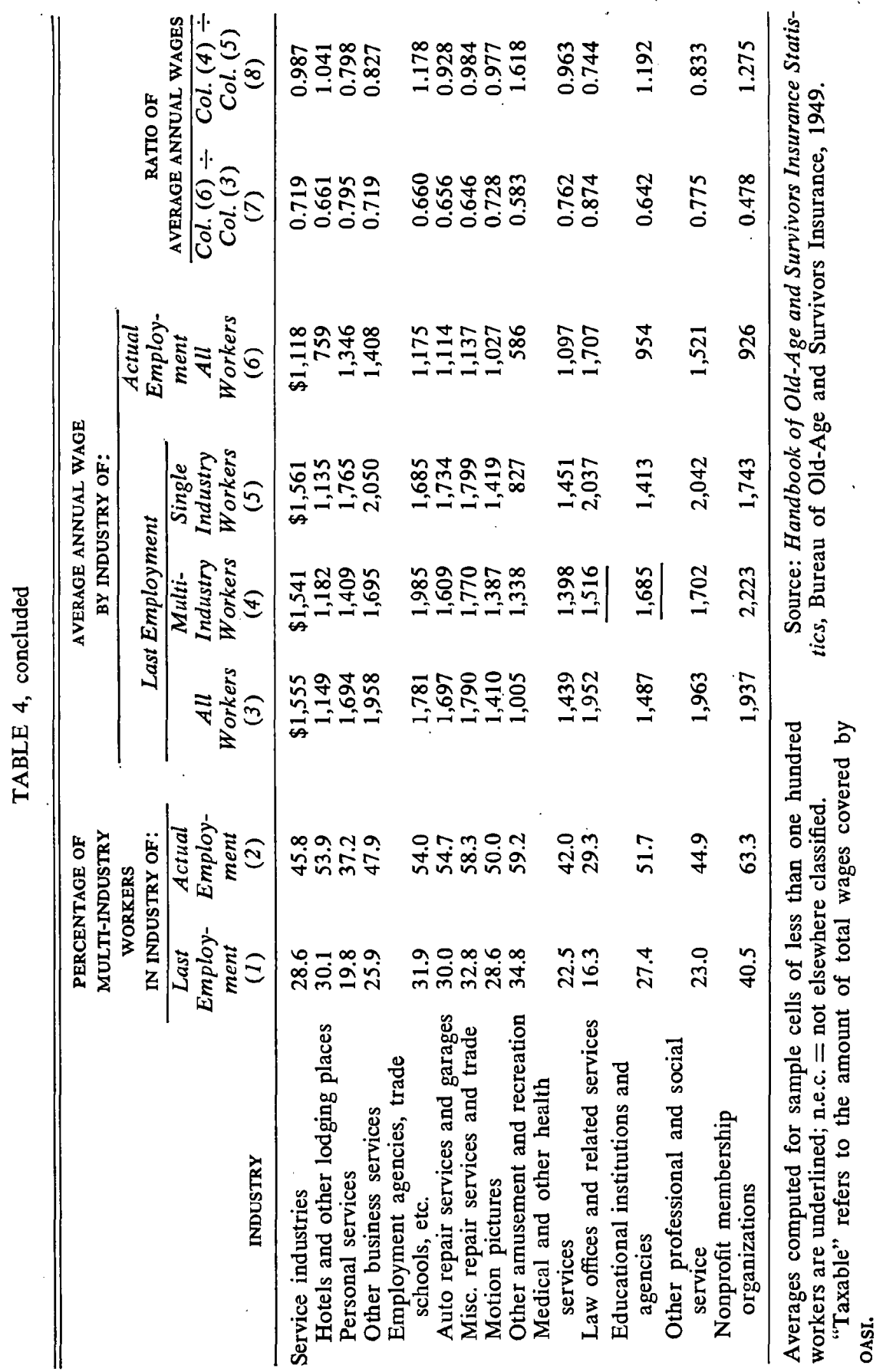


fined to a single industry, in an extreme case 61.8 per cent more. In the remaining fifty-eight industries, multi-industry workers earned less by as much as 43.5 per cent than single-industry employees. The average annual earnings of workers by industry of actual employment can, of course, be expected to be in all cases lower than those of workers classified by industry of last employment. Here again the differences are extremely variable, with earnings by industry of actual employment ranging from 49.1 to 95.9 per cent of earnings classified by industry of last employment. A comparatively close relationship, however, did exist between the annual earnings of all workers classified by industry of last employment and those whose employment was limited solely to the same industries.

The pattern of changes in annual earnings over a period of time cannot be fully appreciated from the OASI data because of the differences in pressures of incomes against the taxable ceilings imposed by the Social Security Act. However, a short-term comparison, presented in Table 5 for the years 1948 and 1949, highlights some of the possible consequences of the different concepts of annual industrial earnings. On the whole, changes in earnings of all males classified by industry of last employment and those who worked in but a single industry have shown fairly closely related movements. In twenty-six of the sixty-eight industries, divergence was less than 1 percentage point and in fifty-two cases less than 2 percentage points. ${ }^{7}$ On the other hand, the difference in movement between the annual earnings of workers who worked in a single industry and the average earnings of all workers who worked in the same industry was more pronounced. In only two industries was the divergence in movements smaller than 1 percentage point, and in only seventeen was it under 5 percentage points. In forty-two industries, divergences ranged from 5 to 10 percentage points, and in seven industries they were 10 to 39 points. Divergencies between earnings. of all workers classified by industry of last employment and those classified by industry of actual employment are substantially similar.

\section{Employment Patterns Affecting Annual Earnings}

The OASI data suggest that variations in the industrial distribution of annual wage and salary incomes are materially affected by the

${ }^{7}$ To measure divergence in the movement of two series, differences in percentage points between the 1948-1949 ratios of each series were used. Because of the nature of the data, they do not differ materially from similar figures obtainable more laboriously in percentage form. 


\section{TABLE 5}

Percentage Change in Average Annual Taxable Wages of Male Covered Workers between 1948 and 1949

\begin{tabular}{|c|c|c|c|c|}
\hline \multirow[b]{3}{*}{ INDUSTRY } & \multicolumn{4}{|c|}{$\begin{array}{l}\text { PERCENTAGE CHANGE IN AVERAGE ANNUAL WAGE } \\
\text { BY INDUSTRY OF: }\end{array}$} \\
\hline & \multicolumn{3}{|c|}{ Last Employment } & \multirow{2}{*}{$\begin{array}{c}\text { Actual Em- } \\
\text { ployment } \\
\text { All } \\
\text { Workers }\end{array}$} \\
\hline & $\begin{array}{c}\text { All } \\
\text { Workers }\end{array}$ & $\begin{array}{l}\text { Multi- } \\
\text { Industry } \\
\text { Workers }\end{array}$ & $\begin{array}{c}\text { Single } \\
\text { Industry } \\
\text { Workers }\end{array}$ & \\
\hline \multicolumn{5}{|l|}{ Mining: } \\
\hline Metal & +0.2 & -6.2 & +0.1 & +6.2 \\
\hline Anthracite & -13.3 & -19.5 & -12.8 & -13.0 \\
\hline Bituminous and other soft-coal & -14.7 & -13.1 & -15.4 & -12.7 \\
\hline Crude petroleum and natural gas & +4.1 & -3.9 & +4.2 & +9.6 \\
\hline Nonmetallic and quarrying & +2.5 & -5.8 & +3.5 & +42.2 \\
\hline \multicolumn{5}{|l|}{ Contract construction: } \\
\hline Building, general contractors & -2.4 & -0.4 & -4.1 & +0.6 \\
\hline $\begin{array}{l}\text { General contractors, other than } \\
\text { building }\end{array}$ & & & & 1108 \\
\hline $\begin{array}{l}\text { building } \\
\text { Special-trade contractors }\end{array}$ & $\begin{array}{l}+1.7 \\
-0.5\end{array}$ & $\begin{array}{l}+0.6 \\
+1.7\end{array}$ & $\begin{array}{l}+3.6 \\
-2.0\end{array}$ & $\begin{array}{r}+10.8 \\
+1.8\end{array}$ \\
\hline \multicolumn{5}{|l|}{ Manufacturing: } \\
\hline Ordnance and accessories & +1.4 & +10.8 & -1.8 & +16.0 \\
\hline Food and kindred products & +4.1 & -1.1 & +4.0 & +12.2 \\
\hline Tobacco manufactures & -5.4 & +4.0 & -6.3 & +0.2 \\
\hline Textile mill products & -3.5 & -1.3 & -4.1 & +0.1 \\
\hline Apparel, fabric products, etc. & -1.7 & -0.3 & -2.7 & +3.5 \\
\hline Lumber and wood products & -0.9 & -3.7 & -0.4 & +3.9 \\
\hline Furniture and fixtures & +2.4 & +1.7 & +0.9 & +12.2 \\
\hline Paper and allied products & +1.3 & -3.8 & 0 & +9.2 \\
\hline Printing, publishing, etc. & +2.4 & +0.9 & +1.7 & +5.7 \\
\hline Chemicals and allied products & +0.4 & -5.8 & -0.2 & +8.3 \\
\hline Petroleum and coal products & +0.6 & -5.6 & +0.2 & +7.7 \\
\hline Rubber products & +1.4 & +6.9 & -0.5 & +7.1 \\
\hline Leather and leather products & -0.2 & +1.7 & -0.5 & +6.2 \\
\hline Stone, clay and glass products & +2.6 & +3.0 & +0.6 & +13.4 \\
\hline Primary metal industries & +0.2 & +4.0 & -1.8 & +9.3 \\
\hline Fabricated metal products & +0.1 & -0.3 & -1.1 & +10.1 \\
\hline Machinery, except electrical & +1.2 & +5.4 & -0.6 & +7.1 \\
\hline Electrical machinery, etc. & +0.3 & +3.0 & -0.9 & +6.7 \\
\hline Transportation equipment & +2.1 & +4.9 & +0.4 & +8.1 \\
\hline Instruments, etc. & +2.3 & +9.7 & -0.8 & +8.5 \\
\hline Misc. manufacturing & +0.5 & +1.4 & -0.8 & +7.9 \\
\hline \multicolumn{5}{|l|}{ Public utilities: } \\
\hline Local railways and bus line & +3.6 & +10.9 & +1.5 & +13.0 \\
\hline Trucking and warehousing for hire & +2.0 & +2.7 & +0.1 & +9.6 \\
\hline Other transportation, except water & 0 & -0.5 & -1.0 & +5.2 \\
\hline Water transportation & +3.7 & -0.4 & +4.9 & +8.2 \\
\hline Services allied to transportation & +5.0 & +9.8 & +2.0 & +12.9 \\
\hline Communication, telephone, etc. & +4.6 & +0.1 & +2.7 & +9.7 \\
\hline Electric and gass & +4.7 & +8.9 & +3.2 & +9.8 \\
\hline Other local utilities and services & -7.3 & -1.1 & -10.0 & -1.2 \\
\hline
\end{tabular}

continued on next page 
TABLE 5, concluded

\begin{tabular}{|c|c|c|c|c|}
\hline \multirow[b]{3}{*}{ INDUSTRY } & \multicolumn{4}{|c|}{$\begin{array}{l}\text { PERCENTAGE CHANGE IN AVERAGE ANNUAL WAGE } \\
\text { BY INDUSTRY OF: }\end{array}$} \\
\hline & \multicolumn{3}{|c|}{ Last Employment } & \multirow{2}{*}{$\begin{array}{c}\text { Actual Em- } \\
\text { ployment } \\
\text { All } \\
\text { Workers }\end{array}$} \\
\hline & $\begin{array}{c}\text { All } \\
\text { Workers }\end{array}$ & $\begin{array}{l}\text { Multi- } \\
\text { Industry } \\
\text { Workers }\end{array}$ & $\begin{array}{c}\text { Single } \\
\text { Industry } \\
\text { Workers }\end{array}$ & \\
\hline \multicolumn{5}{|l|}{ Wholesale and retail trade } \\
\hline Full and limited-function wholesalers & +2.1 & -1.1 & +1.2 & +8.7 \\
\hline Other wholesalers & +2.3 & -4.1 & +2.3 & +10.5 \\
\hline Wholesale and retail trade, n.e.c. & +6.1 & +0.7 & +6.4 & +13.9 \\
\hline Retail general merchandise & +4.6 & -2.4 & +5.4 & +11.9 \\
\hline Retail food and liquor stores & +3.3 & -0.8 & +3.6 & +10.9 \\
\hline Retail automotive & +3.4 & +3.5 & +2.3 & +8.8 \\
\hline Retail apparel and accessories & -1.4 & -4.1 & -1.5 & +4.2 \\
\hline Retail trade, n.e.c. & +1.7 & -1.3 & +2.1 & +9.4 \\
\hline Eating and drinking places & -2.4 & -7.4 & +0.2 & +7.7 \\
\hline Retail filling stations & +5.0 & +3.7 & +6.9 & +14.9 \\
\hline \multicolumn{5}{|l|}{ Finance, insurance and real estate: } \\
\hline Banks and trust companies & +2.6 & +5.2 & +1.8 & +5.5 \\
\hline Security dealers and investment & +3.5 & +1.6 & +3.3 . & +3.1 \\
\hline Finance agencies, n.e.c. & +1.2 & -2.7 & +2.4 & +5.6 \\
\hline Insurance carriers & +1.3 & +6.2 & +0.6 & +4.3 \\
\hline Insurance agents and brokers & +0.2 & -3.2 & +0.5 & +6.8 \\
\hline Real estate & +0.7 & -2.5 & +3.2 & +10.1 \\
\hline Combination offices & +5.7 & +15.9 & +1.9 & +6.9 \\
\hline Holding companies, except real & & & & \\
\hline estate & -11.4 & -17.3 & -9.7 & -13.2 \\
\hline \multicolumn{5}{|l|}{ Service industries: } \\
\hline Hotels and other lodging places & +0.2 & +2.2 & -0.7 & +8.7 \\
\hline Personal services & +1.8 & +2.0 & +1.1 & +7.8 \\
\hline Other business services & +3.7 & -1.5 & +4.3 & +10.2 \\
\hline \multicolumn{5}{|l|}{ Employment agencies, trade } \\
\hline schools, etc. & +11.2 & +6.6 & +16.7 & +14.7 \\
\hline Auto repair services and garages & +2.4 & -2.2 & +4.3 & +8.1 \\
\hline Misc. repair services and trades & +0.9 & -3.0 & +3.3 & +12.3 \\
\hline Motion pictures & +3.8 & +8.1 & +1.9 & +7.8 \\
\hline Other amusement and recreation & -2.7 & -4.8 & +2.9 & +7.1 \\
\hline Medical and other health services & -1.9 & +2.9 & -3.7 & +4.2 \\
\hline Law offices and related services & +5.4 & -10.1 & +7.7 & +15.3 \\
\hline Educational institutions and agencies & -0.3 & +12.7 & -5.2 & +2.5 \\
\hline Other professional and social service & -0.5 & -10.3 & +1.7 & +13.0 \\
\hline Nonprofit membership organizations & -0.2 & +0.5 & +2.8 & +6.9 \\
\hline
\end{tabular}

n.e.c. $=$ not elsewhere classified.

Source: Handbook of Old-Age and Survivors Insurance Statistics, Bureau of Old Age and Survivors Insurance, Volumes for 1948 and 1949.

changing proportion of multi-industry employment and the differences in the earnings of single and multi-industry workers. Many other factors, of course, affect the levels of annual earnings, and hence the industrial distributions, over a period of time. The first of 
these is the standard by which the basic compensation is determined, such as the hourly or weekly rates for those paid on a time basis, and such as piece rates and minimum wage guarantees for those on incentives. Different standards of compensation are also based on the character of the particular incentive formulas in use, on the length of service in the particular establishments, on the appraisals of workers' capabilities or productivity, and on their age, sex and race. Some of these factors account for interplant differentials in the same industry both within the same as well as among the different localities. Levels of annual earnings may also be affected by the number of hours worked by individuals in the course of the year (whether as a result of personal preferences, the seasonal characteristics of the industry to which attached, the fortunes of the firm in which employed, or the over-all business fluctuations), by the prevalence of work at premium rates (overtime, shift differentials, and so forth), by the existence of various bonus payments (profit sharing, Christmas bonuses, and so forth), and by payments for time not worked (vacations, holidays, sickness, call-in-pay, and so forth). Changes in the occupational make-up of the different industries may also have a decided influence on wage distributions.

Distributions of composite groups are a complex of several distribution curves portraying incomes of the more homogeneous groups-a fact well developed by Miller. To the extent, therefore, that levels of wages are affected by numerous factors, it is important to explore the several composite elements of annual wage distributions on a much larger scale than has been done. The standardization procedure undertaken by Miller in his evaluation of changes in the relative importance of different industries between 1939 and 1949 could well be extended to other determinants of income levels. ${ }^{8}$ This in turn suggests a need for many more cross-tabulations of census data. Unquestionably, the main reason why this was not done was a lack of sufficient funds. Yet, additional expenditure of

\footnotetext{
${ }^{8}$ In Income of the American People (Wiley, 1955, pp. 2 f. and pp. $\left.16 \mathrm{ff}.\right)$, Miller found that for males, income distributions for three major occupational groups, which covered about three-fourths of employed men,. were quite symmetrical when viewed separately. These were, of course, broad occupational groupings comprising numerous specific occupational categories. We do not know to what extent the accidental combination of these smaller occupational yet distinct classes of persons in each group, coupled with the many other factors affecting income levels in each subdivision, were responsible for the shape of Miller's distributions. Was the symmetry, in turn, a by-product or combination of several asymetrical distributions or were the symmetries more pronounced in more homogeneous groups? The occupational hourly wage distributions collected for the specific industries by the Bureau of Labor Statistics suggest that the skewness tends to exist when data are taken for the occupations by industry and locality. Is it wiped out for annual incomes comprising both wage and non-wage revenues? Obviously, additional research is needed to provide answers to these questions.
} 
government and private funds in this direction may well be justified.

Household enumerations used by the Census Bureau cannot provide all the information which may have bearing on the patterns of wage and salary incomes. It would be impossible, for example, to obtain information on the relationship between the various wage payment methods found in a given industry and annual earnings except by means of more intensive inquiries conducted in specific industries, combining the establishment and the household approach. The Census Bureau approach could nevertheless provide much more data than it does now both by increasing the detail in its cross tabulations and by exploring further its concept of relating annual incomes to industry and occupation during the census week. More information is needed on the relationship between the occupation and industry during the census week and the occupation and industry which gave rise to the predominant share of wage incomes in the preceding year. More information is also required to determine how seasonal variations in occupational and industrial distribution affect occupational and industrial relationships to income.

Miller's basic conclusions on the narrowing of annual wage differentials probably would not be materially upset were more refined data available, although some of the more detailed observations might possibly have to be modified. His conclusions regarding the relative standing of industries on the basis of the 1939 and 1949 earnings credited to workers would probably be more in question. The very concept of stability used by Miller is not an absolute one. Thus he notes that in only twenty-three out of 117 industries studied, which account for about one-fifth of all workers, did ranks shift by more than one decile. This is, of course, in addition to any change in industry ranking which may have occurred within each decile. It should be noted that deciles referred to by Miller are not those of an array of average annual earnings for the 117 industries. Instead, they are based on a distribution of individual averages into ten approximately equal groups on the basis of the number of workers portrayed by individual averages. The interindustry shifts referred to by Miller are, therefore, a function not only of a change in the relative position of individual industries but of the relative shifts in the size of employment in the different industries as well.

\section{Institutional Factors Influencing Wage Differentials}

An entirely different picture of interindustry shifts emerges when the changing pattern of distributions is examined by means of the more conventional form of deciles. To this end, the 117 industries 
were ranked by their 1939 and 1949 average annual earnings and the positive and negative changes in ranks were arranged in an array on the basis of the relative standing of the individual industries in 1939. The results of this tabulation are shown in Table 6. The

TABLE 6

Change in Ranking of 117 Industries between 1939 and 1949

\begin{tabular}{|c|c|c|c|c|c|c|c|c|c|}
\hline \multicolumn{10}{|c|}{ DECILES } \\
\hline 1 & 2 & 3 & 4 & 5 & 6 & 7 & 8 & 9 & 10 \\
\hline \multicolumn{10}{|c|}{ Change in Ranking " } \\
\hline $\begin{array}{r}0 \\
0 \\
+3 \\
0 \\
-2 \\
+14 \\
-2 \\
+3 \\
+4 \\
+18 \\
-2 \\
0\end{array}$ & $\begin{array}{r}+5 \\
-7 \\
-1 \\
+1 \\
+2 \\
+4 \\
+5 \\
+12 \\
-13 \\
+19 \\
-8\end{array}$ & $\begin{array}{r}-8 \\
-2 \\
+28 \\
+5 \\
-2 \\
-19 \\
-3 \\
-10 \\
+20 \\
+15 \\
-9 \\
+2\end{array}$ & $\begin{array}{r}+30 \\
+6 \\
+5 \\
-10 \\
+13 \\
-6 \\
+2 \\
+4 \\
-4 \\
-9 \\
-12 \\
+17\end{array}$ & $\begin{array}{r}-15 \\
-10 \\
+10 \\
+23 \\
-3 \\
+5 \\
+48 \\
-4 \\
-10 \\
+4 \\
+5\end{array}$ & $\begin{array}{r}+3 \\
+31 \\
+12 \\
+7 \\
-8 \\
+3 \\
+17 \\
+20 \\
+20 \\
+11 \\
+9 \\
-14\end{array}$ & $\begin{array}{r}-3 \\
+22 \\
+2 \\
-17 \\
+7 \\
-46 \\
+2 \\
-19 \\
+32 \\
-4 \\
-31 \\
-9\end{array}$ & $\begin{array}{r}-38 \\
+11 \\
+7 \\
-3 \\
+17 \\
-50 \\
+16 \\
-5 \\
-14 \\
+9 \\
0 \\
+8\end{array}$ & $\begin{array}{r}-8 \\
+13 \\
-13 \\
+1 \\
+15 \\
+10 \\
-3 \\
-13 \\
-6 \\
-33 \\
-40\end{array}$ & $\begin{array}{r}+6 \\
0 \\
-38 \\
+5 \\
-2 \\
-5 \\
-22 \\
-14 \\
+2 \\
0 \\
-20 \\
0\end{array}$ \\
\hline \multicolumn{10}{|c|}{ Average Change } \\
\hline 4.0 & 11.0 & 10.2 & 9.8 & 12.5 & 12.9 & 16.2 & 14.8 & 14.1 & 9.5 \\
\hline \multicolumn{10}{|c|}{ Number of Changes by Twelve or More Places } \\
\hline 2 & 3 & 4 & 4 & 3 & 6 & 6 & 5 & 6 & 4 \\
\hline
\end{tabular}

${ }^{a}$ Industries were ranked on the basis of their 1939 standing and divided sequentially into deciles.

Source: Appendix Table B-4 in the paper by Herman P. Miller in this volume.

largest number of major shifts in the relative standing of individual industries took place in the region of fifth through the ninth decile, although important shifts are scattered throughout the array. This is hardly a portrayal of stability in interindustry location on the basis of annual earnings. ${ }^{9}$ Altogether, forty-six industries out of 117 moved up or down by twelve places or more (one decile or more) between 1939 and 1949.

Miller properly notes that the apparent narrowing of wage differentials in the 1939-1949 decade is a continuation of an historical process. Apparently, the phenomenon was not confined to the United States alone but is also evident in many other parts of the

${ }^{\circ}$ A somewhat different picture emerges if shifts in rank are portrayed by industry standing in the 1949 array. However, such a tabulation also bears out the conclusion that lower displacement of ranks occurred at the extremes of the array and greater ones in its central portion. 
world. ${ }^{10}$ The institutional forces responsible for this trend are many and varied. Some of them, like trade union activity or governmental intervention, may actively force changes in wage patterns, while others, such as differential changes in the productivity of different industries, may passively permit change. Furthermore, the existence of pressures for change may generate some subsidiary activity. For instance, unions frequently find that employers improve conditions in the same or related lines of work to stave off unionization. Thus, the influence of the union may be felt even when it is numerically weak or even unsuccessful in carrying through unionization. This is why, short of detailed institutional studies of specific industries in relatively small labor market areas, it is difficult to develop empirical explanations for the changes in the patterns of wage distribution. This is probably the basic reason for the comparative sketchiness of Miller's treatment of the causal factors in the narrowing of- wage differentials. Essentially, they are not suitable for statistical treatment. ${ }^{11}$

In this connection, the available information on the effects of changing minimum wages under the Fair Labor Standards Act is somewhat more extensive than that relied upon by Miller and is not always in accord with his findings. ${ }^{12}$ The data on the wage distributions of workers in Southern sawmills definitely suggests that the effect of the 75 cent minimum wage was to narrow wage differentials and that it persisted for at least four years. ${ }^{13}$ The data also show that from 1948 to 1951 increases in hourly earnings in lowwage industries subject to the law were substantially higher than in the high-wage industries also subject to the law, but that changes in hourly earnings in the low-wage nonsubject industries did not differ materially from changes in the high-wage subject industries. Thus, the average increase for high-wage subject industries was 121 per cent during the period, in the low-wage nonsubject industries 125 per cent, but in low-wage subject industries 171 per cent. ${ }^{14}$ These conclusions are also supported by a more recent investigation directed at the evaluation of the effects of $\$ 1$ minimum wage. In the

\footnotetext{
${ }^{10}$ See, for example, the following papers in International Labor Review: John T. Dunlop and Melvin Rothbaum, "International Comparisons of Wage Structures," April 1955, pp. 347 ff.; "Recent Trends in Industrial Wages" May 1955, pp. 516 ff.; Earl E. Muntz, "The Decline in Wage Differentials Based on Skill in the United States," June 1955, pp. 575ff.; "Changing Wage Structures: An International Review" March 1956, pp. 275 ff.; and Lloyd G. Reynolds and Cynthia H. Taft, The Evolution of Wage Structure, Yale University Press, 1956.

${ }^{11} \mathrm{Cf}$. Reynolds and Taft, op. cit., pp. $12 \mathrm{f}$.

${ }^{13}$ Results of the Minimum-Wage Increase of 1950: Economic Effects in Selected Low-Wage Industries and Establishments, Dept. of Labor, August 1954.

${ }^{18}$ Ibid., pp. 21 and 24.

${ }^{14}$ Ibid., pp. 109 and $111 \mathrm{ff}$.
} 
short run, this minimum, which became effective on March 1, 1956, resulted in a general narrowing of wage differentials, in industries surveyed, particularly among regions, occupations, and plants of different sizes. The study also concludes that since the Fair Labor Standards Act became effective in 1938, "average hourly earnings of workers in selected low-wage industries generally subject to the Act have increased by a larger percentage than earnings for selected high-wage industries or for all manufacturing workers combined," while "earnings of workers in selected low-wage industries in which the Act is not generally applicable have lagged behind the other three groups, for the period 1938 to 1956 taken as a whole." 15

${ }^{15}$ Studies of the Economic Effects of the $\$ 1.00$ Minimum Wage, Department of Labor, March 1957. 